\title{
Practice Of Accounting Conservatism In MBE Firms
}

Sang Hyun Park, Georgia Regents University, USA

Jaywon Lee, Korea Advanced Institute of Science and Technology (KAIST), South Korea

\begin{abstract}
Managers sometimes manage earnings upward (i.e., engage in earnings management) or guide analyst forecasts downward (i.e., engage in expectation management) to meet or beat analysts' earnings forecasts (MBE). Our results suggest that certain management behavior to achieve MBE is highly associated with firms' level of accounting conservatism. In detail, we find that (1) the level of accounting conservatism decreases as firms achieve MBE in consecutive years, (2) engaging in earnings management to achieve MBE lowers firms' level of conservatism, and (3) firms that achieve MBE in consecutive years (CMBE firms) whose credit rating had been elevated practice less conservative accounting implying that the MBE string itself might act as a substitute for conservative accounting in lowering firms' cost of debt.
\end{abstract}

Keywords: Accounting Conservatism; Earnings Forecast; Earnings Management; Expectation Management

\section{INTRODUCTION}

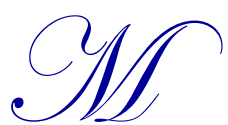

anagers sometimes manage earnings upward or guide analyst forecasts downward to meet or beat analysts' earnings forecasts (hereafter MBE). This is because managers consider analyst forecasts as an important performance threshold (Degeorge et al. 1999). Moreover, the market actually appreciates firms that achieve MBE with a premium (Bartov et al. 2002). Due to such importance of MBE, the number of MBE-achieving firms has increased in recent years (Brown 1997).

However, there has been little research concerning the firms that consistently meet or beat earnings forecast for consecutive years (hereafter CMBE firms) ${ }^{1}$. While most of studies focuse on MBE firms, Kasznik and McNichols (2002) first show that there is a positive relation between MBE consistency and firm value. Bartov et al. (2002) also find that firms with consecutive MBE have a greater premium in the stock market. Recently, Kross et al. (2009) provide evidence that firms with established MBE strings ${ }^{2}$ are more likely to guide analyst forecast downward by providing 'bad news' management forecasts, and the effect of this downward guidance diminishes as a firm's MBE string increases. Nonetheless, none of these studies to our knowledge have yet established the link between CMBE firms and their accounting behavior.

In this study, we focus on one of the most important practice in accounting, the 'accounting conservatism'. This practice guidesfirms to recognize all probable losses as they incur, but defer any revenues until it becomes verifiable. Therefore, firms that practice high degree of accounting conservatism would reflect 'bad news' in their financial statement more timely compared to those that do not (Basu, 1997). In a similar vein, we suspect that firms that consistently release 'good news' around earnings announcement date to achieve MBE practice less conservative accounting.

In this paper, by using firm-year measure of accounting conservatism, we test the relationship between the level of accounting conservatism and the MBE string as well as management behavior. Our evidence suggests that the level of accounting conservatism decreases as firms achieve MBE in consecutive years. Also, the model in this

\footnotetext{
${ }^{1}$ This term is first used in Kross, Ro and Suk (2011).

${ }^{2}$ We use the term 'MBE strings' to depict firms that achieve MBE in consecutive years. 
paper shows that engaging in earnings management to achieve MBE causes firms' level of conservatism to decrease. Finally, we find that CMBE firms with an elevated credit risk use less conservative accounting. This implies that the MBE string itself might act as a substitute for conservative accounting in lowering firms' cost of debt.

Firms that practice high degree of accounting conservatism tend to release verifiable and unbiased information to the public. Hence, the results presented in this study warn users of financial information to be more cautious when analyzing firms with lengthy MBE strings since their level of conservatism is likely to be lower than firms that d not achieve MBS strings. Therefore, while many investors and stockholders appreciate CMBE firms and interpret their MBE string as a sign of improved performance, researchers should consider the propensity of earnings management as well as the quality of earnings within CMBE firms.

Our findings make the following contributions to the accounting literature. First, we provide a direct link between managers' intent to achieve CMBE and accounting conservatism. Many researchers believe that the level of accounting conservatism adjusts to the demand from investors (Watts, 2003a). However, there is also evidence that firms intentionally manage their level of accounting conservatism to achieve managers' specific objective (Jackson and Liu, 2010). This paper adds to the literature on the practice of accounting conservatism by showing that firms do manage their level of accounting conservatism strategically that is beyond reflecting the demand from investors. Second, we show that earnings management plays a larger role in affecting firms' level of conservatism. Watts (2003a) argues that the accounting conservatism limits managers' intent to manage earnings, but few have provided the link between two (Chen et al. 2007; LaFond and Watts, 2008; Iyengar and Zampelli 2010; Jackson and Liu 2010). By showing that earnings management among MBE firms affects the level of accounting conservatism, we provide an indirect relationship between earnings management and accounting conservatism.

The organization of this paper is as follows. In section 2, reviews of prior research on MBE firms and accounting conservatism are discussed followed by the hypothesis development. Section 3 describes the sample and data and presents empirical models to test the hypothesis introduced in section 2. Section 4 reports the results, and Section 5 concludes with a summary and suggestions for further research.

\section{LITERATURE REVIEW AND HYPOTHESIS DEVELOPMENT}

\subsection{Prior Studies On MBE Firms}

The characteristics of MBE firms have been well documented throughout various studies. Degeorge et al. (1999) points out that the analyst earnings forecasts are important performance thresholds that managers try to achieve. In their article, they argue that managers boost their earnings to meet or beat analysts' forecasts. Matsumoto (2002) finds that certain firm characteristics (such as higher transient institutional ownership, greater reliance on implicit claims with their stakeholders, and higher value-relevance of earnings) are associated with incentives to meet or exceed expectations at the earnings announcement. She also examines the propensity for firm having positive abnormal accruals and concludes that earnings management plays a role in helping a firm avoid negative earnings surprise. Consistent with findings that earnings management plays a role in achieving MBE, Payne and Robb (2000) and Roychowdhury (2006) shows that there are anomalous discretionary accruals around an earnings announcement. However, earnings management is not the only way to achieve MBE. Evidence from other literature suggests that expectation management can also be used. Matsumoto (2002) examines whether managers guide analysts' forecasts downward to achieve MBE and finds that downward guidance of forecasts dominates earnings management as a means to avoid negative surprise. Consistent with her argument, Burgstahler and Eames (2006) provide evidence of the upward management of reported earnings while guiding analysts' forecast downward.

Findings in these researches suggest that there are firms that intentionally try to achieve MBE, either through earnings management or expectation management. There are several explanations regarding motivations of these firms. The best way to find it is to observe market response of firms that meet or beat latest analysts' forecasts. Bartov et al. (2002) find that there exists a premium for MBE firms compared to those who fail to meet these expectations. Interestingly, this premium exists even for firms that are likely to achieve MBE through earnings or expectation management. On the contrary, failure to achieve MBE engenders a large negative stock price response (Skinner and Sloan, 2002). Moreover, Kasznik and McNichols (2002) find that firms with an MBE string show a significant drop in 
their stock price at the earnings announcement date if they break the string, while those who don't have a string have no significant change in their stock price.

Some studies on MBE have pointed out the importance of the MBE consistency. Bartov et al. (2002) find that MBE reflects a firm's future performance and this predictive power is only slightly diminished if firms achieve MBE through expectation or earnings management. Also they report that the value premium for a habitual beater is greater than that of sporadic beaters. Consistent with their results, Kasznik and McNichols (2002) show that there is a positive relation between MBE consistency and the market value of the firm, which suggests that the market appreciates firms with a longer MBE string. Therefore, one can easily anticipate that firms that already established MBE string would make an effort to satisfy investors' expectation. To report such earnings more often, firms need to exaggerate earnings by practicing less conservative accounting.

H1: The level of accounting conservatism decreases as firms achieve MBE in consecutive years.

\subsection{The Relationship Between Accounting Conservatism And Earnings Management}

Conservative accounting firms usually understate net assets by recognizing losses in a timely manner than gains (Basu, 1997; Holthausen and Watts, 2001). Accounting conservatism not only ensures the quality of earnings but also acts as a substitute in reducing information asymmetry. LaFond and Watts (2008) found that conservatism reduces the manager's incentives to manipulate accounting numbers, hence reducing information asymmetry. Consistent with this argument, Hui et al. (2009) argue that, by reporting 'bad news' in a timely manner, conservatism reduces information asymmetry in the market as it acts as a substitute for a management forecast.

Since accounting conservatism usually ensures that verifiable information is to be announced, prior studies argue that it limits managers' ability to manipulate their earnings. Chen et al. (2007) show that the degree of earnings manipulation is lower in a conservative regime. They show that conservatism dampens managers' incentive to manage earnings by increasing the current owner's marginal cost to motivate the agent. Iyengar and Zampelli (2010) also support the hypothesis that conservatism limits earnings management opportunities since it improves the reliability of accounting performance. Overall, these studies suggest that there is negative association between conservatism and earnings management.

Often times, unexpected accruals are presumed to be evidence of earnings management. Pae (2007) shows that approximately 63 percent of differential timeliness of the earnings are explained by the accrual component of earnings. In this accrual component, 93 percent of the differential timeliness of accruals is explained by unexpected accruals. Considering the common belief that the differential timeliness of earnings refers to conservatism, these results suggest that earnings management considerably impacts a firm's level of conservatism. Similar to his study, Lara et al. (2009) find that firms with strong-governance and that show a higher level of conservatism tend to use discretionary accruals to inform investors about 'bad news' in a timely manner than 'good news'. Results from both studies imply that firms that practice more conservative accounting are likely to use negative discretionary accruals to report bad news in a timely manner.

Recently, Jackson and Liu (2010) show that firms with conservative allowance can use this account more strategically to avoid missing analysts' earnings forecast. For these firms, it is observed that firms with pre-bad debt expense earnings that are slightly above analysts' earnings forecast reduce their bad debt expense to achieve MBE. Moreover, firms with pre-bad debt expense earnings that are slightly below analysts' earnings forecast even record income-increasing bad debt expense (i.e., negative bad debt expense) to avoid not meeting analysts' forecasts. These types of income-increasing earnings management can be captured in positive discretionary accruals and attenuate the level of conservatism compared to the prior year.

To sum up, results from these previous studies imply that firms that engage in earnings management to achieve MBE might practice less conservative accounting due to the recognition of income-increasing (positive) discretionary accruals.

H2: Firms practice less conservative accounting as they engage in earnings management to achieve MBE. 


\subsection{The Relationship Between Accounting Conservatism And MBE String}

It is possible that firms try to sustain the MBE string in order to send an optimistic signal to market participants, or to extend firms' investment opportunities. Ahmed et al. (2002) argue that borrowing firms, who require financing for a given investment opportunity set, reduce their cost of debt by accepting conservative accounting. On the other hand, even if a firm does not practice rigorous conservative accounting, if that firm has long enough MBE string record, it might appeal to investors as having healthy capital structure. As a result, it is highly likely that this type of firm possesses favorable long-term debt credit rating ${ }^{3}$. Therefore, if investors perceive MBE string as a substitute for the practice of accounting conservatism, managers would try to reflect as many 'good news' as possible in their financial statement to lengthen MBE string. This leads to the final hypothesis of the study.

H3: Within firms that achieve consecutive MBE, the level of accounting conservatism would be lower for firms with high credit ratings.

\section{RESEARCH DESIGN}

\subsection{Sample And Data}

Sample firms are collected from IBES, Compustat, and CRSP for the period of 1988 2009. We take analyst forecasts and actual earnings from IBES and daily price and bid-ask spread data from CRSP. All the other variables which can be seen from firms' financial statements are obtained from Compustat. Long-term debt credit ratings, which are assigned by Standard and Poor's (S\&P), are also obtained from monthly updated Compustat data.

From the intersection of IBES, Compustat, and CRSP data, we obtain 36,543 firm-year observations after eliminating the top and bottom $1 \%$ for size, market to book ratio (hereafter, $\mathrm{M} / \mathrm{B}$ ), leverage, return, earnings, and discretionary accruals. Among them, 15,204 firm-year observations achieved MBE. There are 5,574 individual firms which have an average of 10.81 years.

\subsection{Estimating The Level Of Accounting Conservatism}

Since there had not been a definite measure of accounting conservatism, many researchers had proposed various types of measures (Basu, 1997; Feltham and Ohlson, 1995; Zhang, 2000). Among them, the coefficient estimated from the Basu (1997) model is still widely used and supported by many researchers despite of some shortcomings (Ryan, 2006). Basu (1997) model cannot capture the firm-year level of conservatism, since it can only measure either the firm-level of conservatism, or the year-level of conservatism (which measures the level of conservatism for a specific year by assuming all firms are homogenous). This measure requires several years of observations to acquire firm-level conservatism. For example, to acquire firm-level conservatism by using the Basu (1997) model, we need an estimation period at least four or more years theoretically. Another measure of accounting conservatism proposed by Givoly and Hayn (2000) also requires 6-year estimation period. Later, Penman and Zhang (2002) construct a conservatism score based on inventory, $R \& D$ and advertising reserves. However, Hui et al. (2009) point out that their measure does not consider the overall level of conservatism in a firm's accounting system. Sometimes M/B is used to measure firm-year conservatism. But Roychowdhury and Watts (2007) explain that using $\mathrm{M} / \mathrm{B}$ as a conservatism measure might cause a 'buffer problem' (see, Roychwdhury and Watts, 2007 page 5).

To meet the demand for a firm-year measure of conservatism, Khan and Watts (2009) introduced C_Score which captures both the cross-sectional and time-series characteristics of conservatism simultaneously. Unlike other measures, $C$ _SCore can reflect the timing of conservatism changes and the variation of conservatism across firms within an industry (Khan and Watts, 2009). It is thus a direct measure of firm-year conservatism. To obtain C_Score, annual cross-sectional regression must be run with following model:

$\mathrm{X}_{\mathrm{i}}=\beta_{1}+\beta_{2} \mathrm{D}_{\mathrm{i}}+\mathrm{R}_{\mathrm{i}}\left(\mu_{1}+\mu_{2} \operatorname{Size}_{\mathrm{i}}+\mu_{3} \mathrm{M} / \mathrm{B}_{\mathrm{i}}+\mu_{4} \operatorname{Lev}_{\mathrm{i}}\right)+\mathrm{D}_{\mathrm{i}} \mathrm{R}_{\mathrm{i}}\left(\lambda_{1}+\lambda_{2} \operatorname{Size}_{\mathrm{i}}+\lambda_{3} \mathrm{M} / \mathrm{B}_{\mathrm{i}}+\lambda_{4} \operatorname{Lev}_{\mathrm{i}}\right)+\left(\delta_{1} \operatorname{Size}_{\mathrm{i}}+\delta_{2} \mathrm{M} / \mathrm{B}_{\mathrm{i}}+\right.$ $\delta 3$ Levi $\delta 4$ DiSizei+ $\delta 5$ DiMBi $+\delta 6$ DiLevi $+\varepsilon i$

\footnotetext{
${ }^{3}$ Long-term debt credit ratings are usually assigned by Standard and Poor's (S\&P) and used as a measure of firms' cost of debt. 
For firm i, $X_{i}$ is earnings before extraordinary items, $D_{i}$ is a dummy variable which equals 1 if $R_{i}>0$ or 0 otherwise, where $R_{i}$ is the return over one year ${ }^{4}$. Model also controls for size $\left(\right.$ Size $\left._{i}\right)$, market to book ratio $\left(M / B_{i}\right)$, and leverage $\left(L e v_{i}\right)$. In equation (1), if we define G_Score (timeliness of 'good news' each year) and C_Score (the incremental timeliness of bad news each year) as follows, then equation (1) becomes the Basu (1997) Model. ${ }^{5}$

$G_{-}$Score $_{i}=\beta_{3}=\mu_{1}+\mu_{2} \operatorname{Size}_{i}+\mu_{3} M / B_{i}+\mu_{4} \operatorname{Lev}_{i}$

$C_{-}$Score $_{\mathrm{i}}=\beta_{4}=\lambda_{1}+\lambda_{2} \operatorname{Size}_{\mathrm{i}}+\lambda_{3} \mathrm{M} / \mathrm{B}_{\mathrm{i}}+\lambda_{4} \operatorname{Lev}_{\mathrm{i}}$

After obtaining $\lambda_{1} \sim \lambda_{4}$ from equation (1), each firm's characteristics such as size, market to book ratio, and leverage are again used to derive $C_{-}$Score as in equation (3) ${ }^{6}$.

\subsection{Estimation Of Discretionary Accruals}

We use modified Jones (1991) model proposed by Dechow et al. (1995) to estimate discretionary accruals in this study. ${ }^{7}$ First, we estimate coefficients from following regression model by industry (Fama and French 1997) and year within same industry.

$\mathrm{TA}_{\mathrm{i}, \mathrm{t}}=\mathrm{k}_{1} \frac{1}{\text { Assets }_{\mathrm{i}, \mathrm{t}-1}}+\mathrm{k}_{2} \frac{\Delta \text { Sales }_{\mathrm{i}, \mathrm{t}}}{\text { Assets }_{\mathrm{i}, \mathrm{t}-1}}+\mathrm{k}_{3} \frac{\text { PPE }_{\mathrm{i}, \mathrm{t}}}{\text { Assets }_{\mathrm{i}, \mathrm{t}-1}}+\varepsilon_{i, t}$

For firm $i$ at time $t, T A_{i t}$ is total accruals of a firm deflated by its lagged asset. Total accruals are defined as earnings before extraordinary items minus cash flow from operation. $\Delta$ Sales $_{i, t}$ is the change in revenues over a year, $\Delta R e c_{i, t}$ is the change in accounts receivable over a year, and finally $P P E_{i, t}$ is the gross value of property, plant, and equipment. Dechow et al. (1995) argue that the change in revenue should be adjusted for the change in receivable since it is easier for managers to manage earnings by exerting discretion on revenue recognition of credit sales. Therefore, after obtaining estimates, we use following regression model to calculate non-discretionary accruals.

$\mathrm{NDA}_{i, \mathrm{t}}=\hat{\mathrm{k}}_{1} \frac{1}{\operatorname{Assets}_{\mathrm{i}, \mathrm{t}-1}}+\hat{\mathrm{k}}_{2} \frac{\Delta \text { Sales }_{\mathrm{i}, \mathrm{t}}-\Delta \operatorname{Rec}_{\mathrm{i}, \mathrm{t}}}{\text { Assets }_{\mathrm{i}, \mathrm{t}-1}}+\hat{\mathrm{k}}_{3} \frac{\mathrm{PPE}_{\mathrm{i}, \mathrm{t}}}{\operatorname{Assets}_{\mathrm{i}, \mathrm{t}-1}}$

Then discretionary accruals can be calculated by subtracting non-discretionary accruals from total accruals.

$\mathrm{DA}_{\mathrm{i}, \mathrm{t}}=\mathrm{TA}_{\mathrm{i}, \mathrm{t}}-\mathrm{NDA}_{\mathrm{i}, \mathrm{t}}$

In this paper, we also construct 'per share' discretionary accruals $\left(D A P S_{i, t}\right)$ to compare with actual EPS obtained from IBES. Since $D A_{i, t}$ is already once deflated by Assets $_{i, t-1}$, we re-multiplied Assets $_{i, t-1}$ and then deflated with $\mathrm{CSHO}_{i, t}$ (common shares outstanding).

$\operatorname{DAPS}_{\mathrm{i}, \mathrm{t}}=\mathrm{DA}_{\mathrm{i}, \mathrm{t}} *$ Assets $_{\mathrm{i}, \mathrm{t}-1} / \mathrm{CSHO}_{\mathrm{i}, \mathrm{t}}$

After obtaining $D A P S_{i, t}$, we calculate adjusted EPS as follows.

$$
\mathrm{EPS}_{\mathrm{i}, \mathrm{t}}^{\mathrm{adj}}=\mathrm{EPS}_{\mathrm{i}, \mathrm{t}}-\mathrm{DAPS}_{\mathrm{i}, \mathrm{t}}
$$

\footnotetext{
${ }^{4} R_{i}$ is the annual return which begins the fourth month after the fiscal year end. (Basu, 1997)

${ }^{5}$ The last line in equation (1) is an additional term compared to Basu (1997) Model. Khan and Watts (2009) include this additional term to control the 'main effect'. In other words, this term is needed to control for the firm characteristics separately.

${ }^{6}$ Note that $G \_S c o r e$ is a by-product of the equation (1). Since $C_{-}$Score is a only variable of interest which proxies the level of accounting conservatism, we will no longer mention $G \_S c o r e$ from this point on.

${ }^{7}$ Performance matched accruals model (Kothari et al., 2005) is also used. However, due to the similarity of results, we only report results from modified Jones model (Dechow et al., 1995).
} 


\subsection{Extended Definitions Of Expectation Management And Earnings Management}

Kross et al. (2009) provide evidence that firms with established MBE strings are more likely guide analyst forecasts downward by providing 'bad news' management forecasts compared to firms with no MBE string. However, they also find that the effect of downward guidance via 'bad news' management forecast diminishes as a firm's MBE string increases. That is, the magnitude of downward revision of analysts forecast through expectation management is smaller for firms with established MBE strings compared to firms with no MBE string. Although the attempt of expectation management encourages firms to achieve MBE, it is not considered to affect accounting conservatism. Therefore, within firms with MBE strings, it is important to clarify which management activity has been conducted in prior to achieve MBE.

When collecting analyst forecasts and actual earnings data, we define $f \_$earliest as the first analyst forecast which is announced three days after the prior year's actual earnings announcement, and $f_{-}$latest as the latest analyst forecast which is announced at least three days prior to the actual earnings announcement. To examine expectation management, we follow the definition described in Bartov et al. (2002). Thus, we classify firms having positive (or zero) forecast surprise with negative forecast error as expectation management firms. To examine earnings management, we classify firms with positive forecast surprise but having negative forecast surprise after eliminating discretionary accruals as earnings management firms. ${ }^{8}$

However, there might be a case that a firm engages in both types of management (See figure 1 for more detail). Therefore, we categorize them into three types of management; 1) Expectation-management-only firms. These firms engage in expectation management but not in earnings management. 2) Earnings-management-only firms. These firms engage in earnings management but not in expectation management. 3) Mixed-management firms. These firms engaged in both types of management (expectation management and earnings management) simultaneously. In addition to these three types of management, we refer to firms engaged in either expectation or earnings management to achieve MBE as managed firms. Other firms that don't belong any of above classification, however, still achieve MBE are referred as unmanaged firms.

By the definition, unmanaged firms do not include expectation-management-only firms. However, it is possible that some firms with earnings management might be included in this category. Since the estimation of discretionary accruals is solely based on modified Jones model (Dechow et al., 1995), we might fail to capture earnings management within firms that are already classified as unmanaged firms. Figure 1 depicts the three types of management described above.

\footnotetext{
${ }^{8}$ In this paper, earnings management firms refer to firms who engage in earnings management to achieve MBE. Therefore, by definition, they are firms which have positive discretionary accruals.
} 


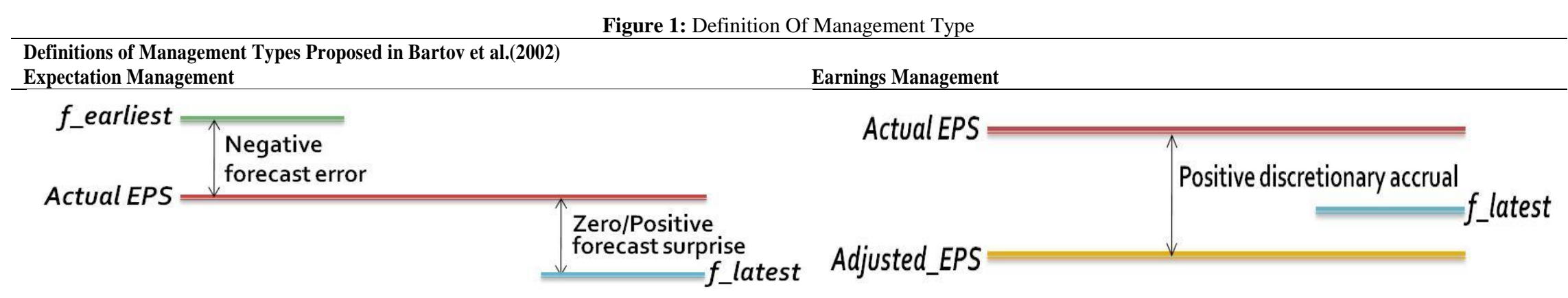

Definitions of Extended Management Types

Expectation-Management-Only

Actual EPS $\frac{\begin{array}{l}\text { Negative } \\ \text { forecast error }\end{array}}{\text { Adjusted_EPS }}$

Mixed Management

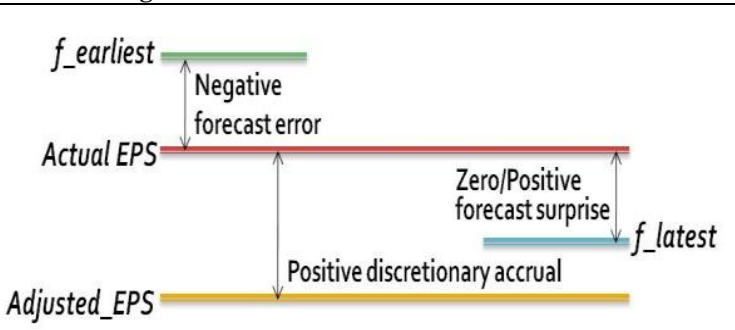

Earnings-Management-Only

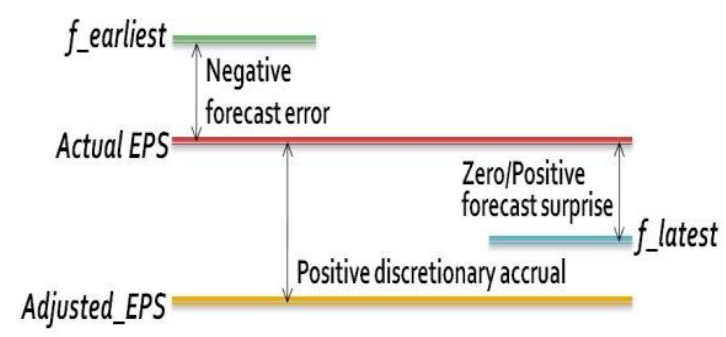

In Figure 1, $\boldsymbol{f}_{-}$earliest is the first analyst forecast which is announced three days after the prior year's actual earnings announcement. $\boldsymbol{f}_{-}$latest is the latest analyst forecast which is announced at least three days prior to the actual earnings announcement. Actual EPS is the EPS at the earnings announcement date. Adjusted_EPS is EPS before discretionary

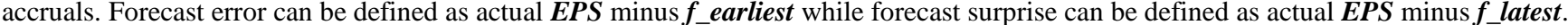

\subsection{Tests of association between conservatism and the MBE string}

To test the relationship between conservatism and MBE strings, we use the following OLS regression models. However, the purpose of regression is not limited to find the association between two. Using this model, one can also find which types of management cause $C_{-} S c o r e$ to increase or decrease.

$\mathrm{C}_{-}$Score $_{\mathrm{i}, \mathrm{t}}=\beta_{0}+\beta_{1}$ MBE_Str $_{\mathrm{i}, \mathrm{t}}+\beta_{2}$ Mgt_Type $_{\mathrm{i}, \mathrm{t}}+\beta_{3}$ Mgt_Type $_{\mathrm{i}, \mathrm{t}} * \mathrm{MBE}_{-} \mathrm{Str}_{\mathrm{i}, \mathrm{t}}+\beta_{4}$ Inv_Cyc $_{\mathrm{i}, \mathrm{t}}+\beta_{5}$ BASprd $_{\mathrm{i}, \mathrm{t}}+\beta_{6} \operatorname{Vol}_{\mathrm{i}, \mathrm{t}}+\beta_{7}$ ROA $_{\mathrm{i}, \mathrm{t}}+\sum_{\mathrm{j}=1}^{48} \beta_{7+\mathrm{j}} \mathrm{SIC}_{-} \mathrm{D}_{\mathrm{j}}+$ $\sum_{\mathrm{k}=1}^{19} \beta_{55+\mathrm{k}} \mathrm{Yr}_{-} \mathrm{D}_{\mathrm{k}}+\varepsilon_{\mathrm{i}, \mathrm{t}}$ 
In equation (9), MBE_str $r_{i, t}$ indicates the number of established MBE string for firm $i$ at year $t$.Mgt_Type is a dummy variable which represents a firm's type of management to achieve MBE. Thus, it is replaced by earningsmanagement-only (Ern_Mgt_D), expectation-management-only (Exp_Mgt_D), or unmanaged (Un_Mgt_D) dummy variable when estimating. Ern_Mgt_D (Exp_Mgt_D) equals 1 if a firm achieve MBE through earningsmanagement-only (expectation-management-only), otherwise equals 0 . We define the variable in such way to separate the effect of earnings management (expectation management) from expectation management (earnings management). From above equation, we expect $\beta_{1}$ to be negative, consistent with H1. We also expect $\beta_{2}$ would be negative when Mgt_Type is Ern_Mgt_D, consistent with H2. However, we make no assumption on $\beta_{2}$ when $M g t \_T y p e$ is either Exp_Mgt_D or $U n \_M g t \_D$.

We include the investment cycle (Inv_Cyc), bid-ask spread (BASprd), return volatility (Vol), and return on asset $(R O A)$ as control variables. Khan and Watts (2009) show that firm-specific uncertainty such as the investment cycle and return volatility are positively related to conservatism. And these relationships are well captured when using $C \_$Score as a dependent variable from Panel regression. They argue that a long investment cycle increases the uncertainty of a firm since it increases the difficulty in estimating future cash flow which in turn might lead to larger losses. Thus, the agency problem arises and lenders, as well as stockholders, demand that those firms be more conservative. Note that Inv_Cyc is a decreasing measure of the length of the investment cycle defined as the depreciation expense deflated by lagged assets. Therefore, the positive association between conservatism and the length of the investment cycle would result in a negative sign for the coefficient of Inv_Cyc when a regression model uses $C_{-}$Score as dependent variable.

LaFond and Watts (2008) show that level of accounting conservatism increases as information asymmetry increases. Since the practice of accounting conservatism reduces a manager's incentives and ability to manipulate earnings, it reduces information asymmetry. Therefore, as information increases, the demand for conservatism increases to offset the information asymmetry that has already been generated. Again, Khan and Watts (2009) successfully demonstrate that there is a positive association between average bid-ask spread for a year (which is a proxy for information asymmetry) and $C_{-}$Score.

Many researchers such as Campbell and Hentschel (1992), and Christie (1982) find a negative relationship between return and return volatility. Since firms that practice more conservative accounting reflect 'bad news' much sooner than 'good news' in their earnings, Khan and Watts (2009) expect that return volatility would be much higher

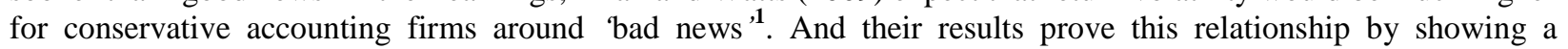
positive correlation between $C_{-} S$ Scroe and return volatility.

Givoly and Hayn (2000) find that a decrease in ROA is dominant when the overall level of accounting conservatism increases. Consistent with their arguments, Watts (2003b) finds that the negative ROA can be easily found among conservative firms. By showing mean ROAs in each C_Score deciles, Khan and Watts (2009) prove that $C_{-}$Score also captures this negative relationship between ROA and accounting conservatism.

It is also known that the market to book ratio (e.g., Watts, 2003a), size (e.g., Easley et al., 2002), and leverage (e.g., Watts and Zimmerman, 1990) are directly related to firm's level of accounting conservatism. ${ }^{2}$ However, we exclude these variables in equation (9), since these variables are already considered in making C_Score. Not surprisingly, all coefficients become insignificant when including these variables. Finally, SIC (SIC_D) and year (Yr_D) dummy variables are also included to capture industry and year variation.

In addition to equation (9), we also test the following model that includes all three types of managements to o the marginal effect of each management type when controlled for each other.

\footnotetext{
${ }^{1}$ Bad news' implies low return of a firm. Therefore return volatility increases since there is a positive association between return and return volatility.

${ }^{2}$ See Khan and Watts (2009) pp. 134 135 for more details.
} 
$\mathrm{C}_{\mathrm{Score}_{i, \mathrm{t}}}=\beta_{0}+\beta_{1} \mathrm{MBE}_{\mathrm{str}_{\mathrm{i}, \mathrm{t}}}+\beta_{2} \operatorname{Exp}_{\mathrm{Mgt}_{\mathrm{i}, \mathrm{t}}}+\beta_{3} \operatorname{Exp}_{\mathrm{Mgt}_{\mathrm{D}, \mathrm{t}}} * \mathrm{MBE}_{\mathrm{str}_{\mathrm{i}, \mathrm{t}}}+\beta_{4} \operatorname{Ern}_{\mathrm{Mgt}_{\mathrm{Di}, \mathrm{t}}}+\beta_{5} \operatorname{Ern}_{\mathrm{Mgt}_{\mathrm{D}}, \mathrm{t}} * \mathrm{MBE}_{\mathrm{str}}+$ $\beta_{6} \mathrm{Un}_{\mathrm{Mgt}_{\mathrm{Di}} \mathrm{t}}+\beta_{7} \mathrm{Un}_{\mathrm{Mgt}_{\mathrm{D}}, \mathrm{t}} * \mathrm{MBE}_{\mathrm{str}}+\beta_{8} \operatorname{Inv}_{\mathrm{Cyc}}+\beta_{\mathrm{i}, \mathrm{t}} \mathrm{BASprd}_{\mathrm{i}, \mathrm{t}}+\beta_{10} \operatorname{Vol}_{\mathrm{i}, \mathrm{t}}+\beta_{11} \mathrm{ROA}_{\mathrm{i}, \mathrm{t}}+\sum_{\mathrm{j}=1}^{48} \beta_{11+\mathrm{j}}$ SIC $_{-} \mathrm{D}_{\mathrm{j}}+$ $\sum_{\mathrm{k}=1}^{19} \beta_{59+\mathrm{k}} \mathrm{Yr}_{-} \mathrm{D}_{\mathrm{k}}+\varepsilon_{\mathrm{i}, \mathrm{t}}$

In above equation, we exclude mixed-management for two reasons. First, mixed-management involves the intersection of earnings-management and expectation-management. Thus, result can be insignificant if the effect from both management types on $C \_S c o r e$ differ. For example, assume that earnings-management causes $C \_S c o r e$ to decrease while expectation-management causes $C_{-}$Score to increase. In this case, effects on C_Score from mixedmanagement cases are unclear, since it offsets the effects of both management types. Another reason is to avoid the full-rank problem when adding the three different types of management in one regression model. Because all samples can be classified into one of four types of management (expectation-management-only, earningsmanagement-only, mixed-management, or unmanaged), including mixed-management induces the full-rank problem.

Because all cases are mutually exclusive, adding three dummy variables (as well as their interaction terms) into one regression model would not change the result. Hence, in equation (10), we expect signs of $\beta_{1}$ and $\beta_{4}$ to be negative.

\subsection{Alternative Model For Testing The Association Between Conservatism And MBE String}

The degree of earnings management in this paper denotes 'the amount of discretionary accruals used to achieve MBE through earnings management'. Simply, the degree of earnings management is 'per share' discretionary accruals (DAPS) times the earnings management dummy variable $\left(E r n \_M g t D\right)$.

Ern_Mgt $_{i, t}=$ DAPS $_{i, t} *$ Ern_Mgt_D $_{i}, t$

Unlike earnings management, there is no way to examine the degree of expectation management. One can only check whether firms have achieved MBE via expectation management or not. Unmanaged firms, by definition, simply denote firms that achieve MBE without any type of management. In sum, earnings management is the only management type for which we can substitute the dummy variable into the variable $\left(E r n \_M g t\right)$ which has an actual value. Therefore, we substitute $E r n_{-} M g t_{-} D$ with $E r n_{-} M g t$ and rewrite equation (10) as follows. As in the equation (10), we expect signs of $\beta_{1}$ and $\beta_{4}$ to be also negative.

C_Score $_{i, t}=\beta_{0}+\beta_{1}$ MBE_str ${ }_{i, t}+\beta_{2}$ Exp_Mgt_D $_{i, t}+\beta_{3}$ Exp_Mgt_D $_{i, t} *$ MBE_str $_{i, t}+\beta_{4}$ Ern_Mgt $_{i, t}+\beta_{5}$ Ern_Mgt $_{i, t} *$

MBE_str $_{i, t}+\beta_{6} U_{-}$Mgt_D $_{i, t}+\beta_{7}$ Un_Mgt_D $_{i, t} *$ MBE_str $_{i, t}+\beta_{8}$ Inv_Cyc $_{i, t}+\beta_{9}$ BASprd $_{i, t}+\beta_{10} \operatorname{Vol}_{i, t}+\beta_{11}$ ROA $_{i, t}+$

$\sum_{\mathrm{j}=1}^{16} \beta_{11+\mathrm{j}}$ SIC_ $_{-} \mathrm{D}_{\mathrm{j}}+\sum_{\mathrm{k}=1}^{19} \beta_{27+\mathrm{k}} \mathrm{Yr}_{-} \mathrm{D}_{\mathrm{k}}+\varepsilon_{\mathrm{i}, \mathrm{t}}$

\section{RESULTS}

\subsection{Descriptive Statistics}

Descriptive statistics of variables are shown in Table 1. We use CSRP to calculate the average bid-ask spread of a firm and Compustat and IBES to compute all other variables. Average C_Score is 0.0908 with standard deviation 0.0926. Both the average and standard deviations are slightly lower than those of Khan and Watts $(2009)^{3}$. Exp_Mgt_D,Ern_Mgt_D, and Un_Mgt_D are dummy variables which indicate expectation-management-only, earnings-management-only, and unmanaged firms, respectively. Therefore, the mean values of these three variables represent the portion of firms that engage in each type of management to achieve MBE. Results show that the portion of earnings-management-only firms (0.0966) is greater than the portion of expectation-management-only firms (0.0692). Not surprisingly, the portion of unmanaged firms $(0.3465)$ is the greatest among three, which indicates that many firms meet or beat earnings without engaging in any types of management activities. However, note that there is no guarantee that firms classified as Unmanaged do not engage in management activities due to the

\footnotetext{
${ }^{3}$ In their paper, they report that average C_Score is 0.105 and standard deviations are 0.139 with 115,516 firm-years between 1963 and 2005. 
misspecification of model. Ern_Mgt is a level of discretionary accruals needed to achieve MBE. Thus it only includes positive discretionary accruals among MBE firms. Table 1 shows there are an average of 0.1786 discretionary accruals used to achieve MBE.

Table 1: Descriptive Statistics On Independent And Control Variables

\begin{tabular}{|c|c|c|c|c|c|c|c|c|c|c|}
\hline & \# of obs. & Mean & Stdev. & $5 \%$ & $10 \%$ & $25 \%$ & $50 \%$ & $75 \%$ & $90 \%$ & $95 \%$ \\
\hline \multicolumn{11}{|c|}{ Dependent Variable } \\
\hline C_Score & 36543 & 0.0908 & 0.0926 & -0.0648 & -0.0278 & 0.0331 & 0.0963 & 0.1484 & 0.1941 & 0.2286 \\
\hline \multicolumn{11}{|c|}{ Independent Variables } \\
\hline MBE_str & 36543 & 1.5704 & 2.1253 & 0.0000 & 0.0000 & 0.0000 & 1.0000 & 2.0000 & 4.0000 & 6.0000 \\
\hline Inv_Cyc & 36543 & 0.0529 & 0.0335 & 0.0157 & 0.0214 & 0.0321 & 0.0460 & 0.0648 & 0.0907 & 0.1134 \\
\hline BASprd & 34229 & 0.0219 & 0.0250 & 0.0010 & 0.0015 & 0.0050 & 0.0144 & 0.0295 & 0.0506 & 0.0684 \\
\hline Vol & 36543 & 0.0328 & 0.0194 & 0.0128 & 0.0152 & 0.0206 & 0.0295 & 0.0407 & 0.0535 & 0.0629 \\
\hline ROA & 36543 & 0.0184 & 0.1537 & -0.2298 & -0.0972 & 0.0066 & 0.0449 & 0.0831 & 0.1252 & 0.1574 \\
\hline Exp_Mgt_D & 36543 & 0.0692 & 0.2539 & 0.0000 & 0.0000 & 0.0000 & 0.0000 & 0.0000 & 1.0000 & 1.0000 \\
\hline Ern_Mgt_D & 36543 & 0.0966 & 0.2954 & 0.0000 & 0.0000 & 0.0000 & 0.0000 & 0.0000 & 1.0000 & 1.0000 \\
\hline Ern_Mgt & 36543 & 0.1786 & 0.7051 & 0.0000 & 0.0000 & 0.0000 & 0.0000 & 0.0000 & 0.4594 & 1.1375 \\
\hline Un_Mgt_D & 36543 & 0.3465 & 0.4759 & 0.0000 & 0.0000 & 0.0000 & 0.0000 & 1.0000 & 1.0000 & 1.0000 \\
\hline DA & 36543 & 0.0020 & 0.0800 & -0.1356 & -0.0908 & -0.0362 & 0.0050 & 0.0430 & 0.0906 & 0.1300 \\
\hline DAPS & 36543 & 0.0948 & 1.8384 & -2.1237 & -1.3101 & -0.4574 & 0.0553 & 0.6130 & 1.5438 & 2.4429 \\
\hline \multicolumn{11}{|l|}{ Other Variables } \\
\hline Ern & 36543 & 0.0250 & 0.1165 & -0.1904 & -0.0962 & 0.0098 & 0.0506 & 0.0790 & 0.1128 & 0.1425 \\
\hline Size & 36543 & 6.0303 & 1.8165 & 3.2175 & 3.7332 & 4.6797 & 5.9370 & 7.2768 & 8.5213 & 9.2477 \\
\hline$M / B$ & 36543 & 2.8024 & 2.6246 & 0.6827 & 0.8994 & 1.3386 & 2.0602 & 3.3443 & 5.4455 & 7.4853 \\
\hline Lev & 36543 & 0.4116 & 0.6578 & 0.0000 & 0.0000 & 0.0216 & 0.1757 & 0.5090 & 1.0767 & 1.6448 \\
\hline Ret & 36543 & 0.0748 & 0.5141 & -0.5874 & -0.4738 & -0.2516 & 0.0021 & 0.2850 & 0.6623 & 1.0025 \\
\hline Asset & 36543 & 2124.2 & 6218.0 & 27.0 & 43.5 & 107.0 & 353.0 & 1357.9 & 4646.3 & 10095.0 \\
\hline Sale & 36543 & 1993.2 & 5883.7 & 17.7 & 36.1 & 107.7 & 374.7 & 1330.1 & 4453.5 & 9195.0 \\
\hline $\operatorname{Rec}$ & 36543 & 289.5 & 1134.5 & 1.5 & 4.0 & 13.8 & 47.7 & 176.5 & 572.2 & 1178.0 \\
\hline$P P E$ & 36543 & 1504.3 & 5105.8 & 6.0 & 11.3 & 36.9 & 158.0 & 745.8 & 3060.6 & 7020.9 \\
\hline
\end{tabular}

Table 1 shows descriptive statistics for 36,543 firm-year observations. $C$ Score $=$ Measure of accounting conservatism suggested by Khan and Watts(2010) $M B E$ str = Number of consecutive MBE string. Inv_Cyc = Decreasing measure of the length of the investment cycle, defined as depreciation expense deflated by lagged assets. BASprd = Bid-Ask spread scaled by the price of the day. Bid-Ask spread for a firm year is the average of the daily spread for a year. Vol $=$ Standard deviation of return for a year. $R O A=$ Return on assets, defined as net income deflated by total assets. Ern $M g t=$ degree of earnings management needed to achieve MBE, defined as DAPS times Ern $M g t \_$. Ern $\_g g t D=1$ if firms achieve MBE through earnings-management-only and 0 otherwise. Exp_Mgt_D = 1 if firms achieve MBE through expectation-management-only and 0 otherwise. $U n \_M g t \_D=1$ if firms achieve MBE without any management activities and 0 otherwise. $D A=$ Discretionary accruals obtained from modified Jones model (Dechow, Sloan, and Sweeney, 1995 ). $D A P S=$ 'per share' discretionary accruals, defined as DA times lagged assets scaled by common shares outstanding. Other variables are variables which are used to calculate C Score or discretionary accruals. Ern $=$ Net income before extraordinary items scaled by lagged market value of equity. Size $=$ Natural log of market value of equity. Lev $=$ Longterm debt plus short term debt deflated by market value of equity. Ret $=$ Annual return which begins the fourth month after the fiscal year end. Asset $=$ Total asset for a year. Sale $=$ Total sales revenue for a year. $\operatorname{Rec}=$ Accounts receivable for a year. $P P E=$ The gross value of property, plant and equipment.

\footnotetext{
${ }^{1}$ Since $E r n \_M g t=D A P S * E r n \_M g t \_D$ and $D A P S$ is 'per share' value, $E r n \_M g t$ is also a 'per share' value.
} 
Table 2 shows a correlation matrix with Pearson correlation at the top triangle and Spearman correlation at the bottom triangle. Most correlations are significant at the $1 \%$ level except two (C_Score \& Inv_Cyc and ROA \& $\left.I n v \_C y c\right)$. C_Score shows significantly negative correlations with $M B E \_s t r$ and Ern_Mgt which is consistent with our main prediction. And directions of other correlations such as C_Score \& Inv_Cyc (spearman only), C_Score \& BASprd, C_Score \& Vol, C_Score \& ROA are same as previous literatures. ${ }^{13}$

Table 2: Correlation Matrix (Pearson Top And Spearman Bottom)

\begin{tabular}{|c|c|c|c|c|c|c|c|}
\hline & C_Score & MBE_str & Inv_Cyc & BASprd & Vol & ROA & Ern_Mgt \\
\hline C_Score & 1 & $\begin{array}{c}-0.1898 \\
(<.0001)\end{array}$ & $\begin{array}{c}0.0029 \\
(0.5788)\end{array}$ & $\begin{array}{c}0.4100 \\
(<.0001)\end{array}$ & $\begin{array}{c}0.3462 \\
(<.0001)\end{array}$ & $\begin{array}{c}-0.2505 \\
(<.0001)\end{array}$ & $\begin{array}{c}-0.0780 \\
(<.0001)\end{array}$ \\
\hline MBE_str & $\begin{array}{l}-0.1908 \\
(<.0001)\end{array}$ & 1 & $\begin{array}{l}-0.0438 \\
(<.0001)\end{array}$ & $\begin{array}{l}-0.2329 \\
(<.0001)\end{array}$ & $\begin{array}{l}-0.1030 \\
(<.0001)\end{array}$ & $\begin{array}{c}0.1516 \\
(<.0001)\end{array}$ & $\begin{array}{c}0.1382 \\
(<.0001)\end{array}$ \\
\hline Inv_Cyc & $\begin{array}{c}-0.0278 \\
(<.0001)\end{array}$ & $\begin{array}{c}-0.0176 \\
(0.0008)\end{array}$ & 1 & $\begin{array}{c}0.0557 \\
(<.0001)\end{array}$ & $\begin{array}{c}0.0708 \\
(<.0001)\end{array}$ & $\begin{array}{l}-0.0035 \\
(0.4993)\end{array}$ & $\begin{array}{c}-0.0757 \\
(<.0001)\end{array}$ \\
\hline BASprd & $\begin{array}{c}0.4199 \\
(<.0001)\end{array}$ & $\begin{array}{c}-0.2589 \\
(<.0001)\end{array}$ & $\begin{array}{c}0.0861 \\
(<.0001)\end{array}$ & 1 & $\begin{array}{c}0.4062 \\
(<.0001)\end{array}$ & $\begin{array}{l}-0.1600 \\
(<.0001)\end{array}$ & $\begin{array}{c}-0.0818 \\
(<.0001)\end{array}$ \\
\hline Vol & $\begin{array}{c}0.4227 \\
(<.0001)\end{array}$ & $\begin{array}{c}-0.0886 \\
(<.0001)\end{array}$ & $\begin{array}{c}0.0489 \\
(<.0001)\end{array}$ & $\begin{array}{c}0.4072 \\
(<.0001)\end{array}$ & 1 & $\begin{array}{l}-0.3315 \\
(<.0001)\end{array}$ & $\begin{array}{c}-0.0861 \\
(<.0001)\end{array}$ \\
\hline ROA & $\begin{array}{c}-0.3703 \\
(<.0001)\end{array}$ & $\begin{array}{c}0.2578 \\
(<.0001)\end{array}$ & $\begin{array}{c}0.0223 \\
(<.0001)\end{array}$ & $\begin{array}{c}-0.1981 \\
(<.0001)\end{array}$ & $\begin{array}{c}-0.2524 \\
(<.0001)\end{array}$ & 1 & $\begin{array}{c}0.0823 \\
(<.0001)\end{array}$ \\
\hline Ern_Mgt & $\begin{array}{l}-0.1222 \\
(<.0001)\end{array}$ & $\begin{array}{c}0.3603 \\
(<.0001) \\
\end{array}$ & $\begin{array}{l}-0.0920 \\
(<.0001)\end{array}$ & $\begin{array}{c}-0.1188 \\
(<.0001)\end{array}$ & $\begin{array}{l}-0.0876 \\
(<.0001)\end{array}$ & $\begin{array}{c}0.2234 \\
(<.0001)\end{array}$ & 1 \\
\hline
\end{tabular}

Table 2 shows the correlation matrix among dependent and independent variables. In this table, the top triangle shows Pearson correlation while the bottom triangle shows Spearman correlation. Except two (which are shown in Bold type), most of correlations are significant with p-values which are less than 0.001 . Variable descriptions are same as those in the Table 1.

\subsection{Average Level Of Accounting Conservatism Across MBE String}

Table 3, Panel A shows the average C_Score in response to the MBE string as well as the number of firms in each management type. The numbers in parentheses describe the portion of each management type compared to the total number of firms in each MBE string. Consistent with findings in Table 1, the portion of unmanaged firms is the largest among the four different types of management, and it occupies over 50\% across the MBE string. The portion of expectation-management-only firms when $M B E_{-}$str is 1 is 0.1362 while that of earnings-managementonly firms is 0.1248. Thus, we can argue that firms that achieve MBE for the first time after a break in the MBE string engage in expectation management slightly more than earnings management. However, this tendency of management is reversed after two consecutive MBE years. Within firms with more than two consecutive MBE years, the portion of earnings management firms is significantly larger than the portion of expectation management firms. In Panel B, we find that even after including the first year observations, on average, the portion of earningsmanagement-only firms is $7 \%$ larger than the portion of expectation-management-only firms. This indicates the number of earnings-management-only firms is 1.59 times larger than the number of expectation-management-only firms. Panel B also shows the results from the two sample $t$-test. The $t$-statistic is 6.593 which is large enough to reject null. Therefore, one can argue that firms engage in earnings management more compared to expectation management when achieving MBE. Moreover, albeit weak, the portion of earnings-management-only firms increases up to 6 consecutive MBE years, while those of expectation-management-only firms remain steady. Most notably, second column in Panel A, Table 3 shows that $C \_S c o r e$ decreases as MBE_str increases, which is consistent with Hypothesis 1 . Figure 2 clearly depicts this relationship as we plot corresponding $C \_s c o r e$ for each $M B E \_s t r$.

\footnotetext{
${ }^{13}$ See Khan and Watts (2009) pp.140 and 143.
} 
Table 3: The Level Of Accounting Conservatism Across MBE String

\begin{tabular}{|c|c|c|c|c|c|c|}
\hline \multicolumn{7}{|l|}{ Panel A } \\
\hline \multirow[b]{2}{*}{ MBE_str } & \multirow[b]{2}{*}{ C_Score } & \multicolumn{5}{|c|}{ Number of } \\
\hline & & Exp_Mgt-Only & Ern_Mgt-Only & Mixed-Management & Unmanaged & Total \\
\hline \multirow[t]{2}{*}{0} & 0.1067 & N/A & N/A & N/A & N/A & 15204 \\
\hline & & N/A & N/A & N/A & N/A & \\
\hline \multirow[t]{2}{*}{1} & 0.0949 & 1094 & 1002 & 1049 & 4887 & 8032 \\
\hline & & $(0.1362)$ & $(0.1248)$ & $(0.1306)$ & $(0.6084)$ & \\
\hline \multirow[t]{2}{*}{2} & 0.0813 & 528 & 920 & 580 & 3089 & 5117 \\
\hline & & $(0.1032)$ & $(0.1798)$ & $(0.1133)$ & $(0.6037)$ & \\
\hline \multirow[t]{2}{*}{3} & 0.0720 & 326 & 584 & 314 & 1841 & 3065 \\
\hline & & $(0.1064)$ & $(0.1905)$ & $(0.1024)$ & $(0.6007)$ & \\
\hline \multirow[t]{2}{*}{4} & 0.0699 & 190 & 345 & 219 & 1045 & 1799 \\
\hline & & $(0.1056)$ & $(0.1918)$ & $(0.1217)$ & $(0.5809)$ & \\
\hline \multirow[t]{2}{*}{5} & 0.0605 & 124 & 238 & 155 & 605 & 1122 \\
\hline & & $(0.1105)$ & $(0.2121)$ & $(0.1381)$ & $(0.5392)$ & \\
\hline \multirow[t]{2}{*}{6} & 0.0581 & 86 & 160 & 108 & 399 & 753 \\
\hline & & $(0.1142)$ & $(0.2125)$ & $(0.1434)$ & $(0.5299)$ & \\
\hline \multirow[t]{2}{*}{7} & 0.0555 & 57 & 105 & 67 & 289 & 518 \\
\hline & & $(0.1100)$ & $(0.2027)$ & $(0.1293)$ & $(0.5579)$ & \\
\hline \multirow[t]{2}{*}{8} & 0.0410 & 39 & 70 & 47 & 181 & 337 \\
\hline & & $(0.1157)$ & $(0.2077)$ & $(0.1395)$ & $(0.5371)$ & \\
\hline \multirow[t]{2}{*}{9} & 0.0349 & 34 & 48 & 30 & 110 & 222 \\
\hline & & $(0.1532)$ & $(0.2162)$ & $(0.1351)$ & $(0.4955)$ & \\
\hline \multirow[t]{2}{*}{$10<=$} & 0.0249 & 52 & 59 & 47 & 216 & 374 \\
\hline & & $(0.1390)$ & $(0.1578)$ & $(0.1257)$ & $(0.5775)$ & \\
\hline
\end{tabular}

Panel A reports the average $C \_$Score across MBE string as well as number of observations for each type of management. Second column shows that average $C$ _SCore decreases as MBE_str increases. The number in parentheses represents the portion of each management type compared to the total number in the respective MBE string.

\begin{tabular}{|c|c|c|c|}
\hline \multicolumn{4}{|l|}{ Panel B } \\
\hline Management Type & \# of obs. & Mean portion & Standard deviation \\
\hline Exp_Mgt-Only & 10 & 0.1194 & 0.0171 \\
\hline Ern_Mgt-Only & 10 & 0.1896 & 0.0290 \\
\hline \multicolumn{4}{|c|}{ H0: Mean portion of Exp_Mgt-Only $\geq$ Mean portion of Ern_Mgt-Only } \\
\hline \multirow{2}{*}{\multicolumn{2}{|c|}{$\begin{array}{l}\text { t-statistic } \\
6.593\end{array}$}} & p-value & \\
\hline & & $<.0001$ & \\
\hline
\end{tabular}




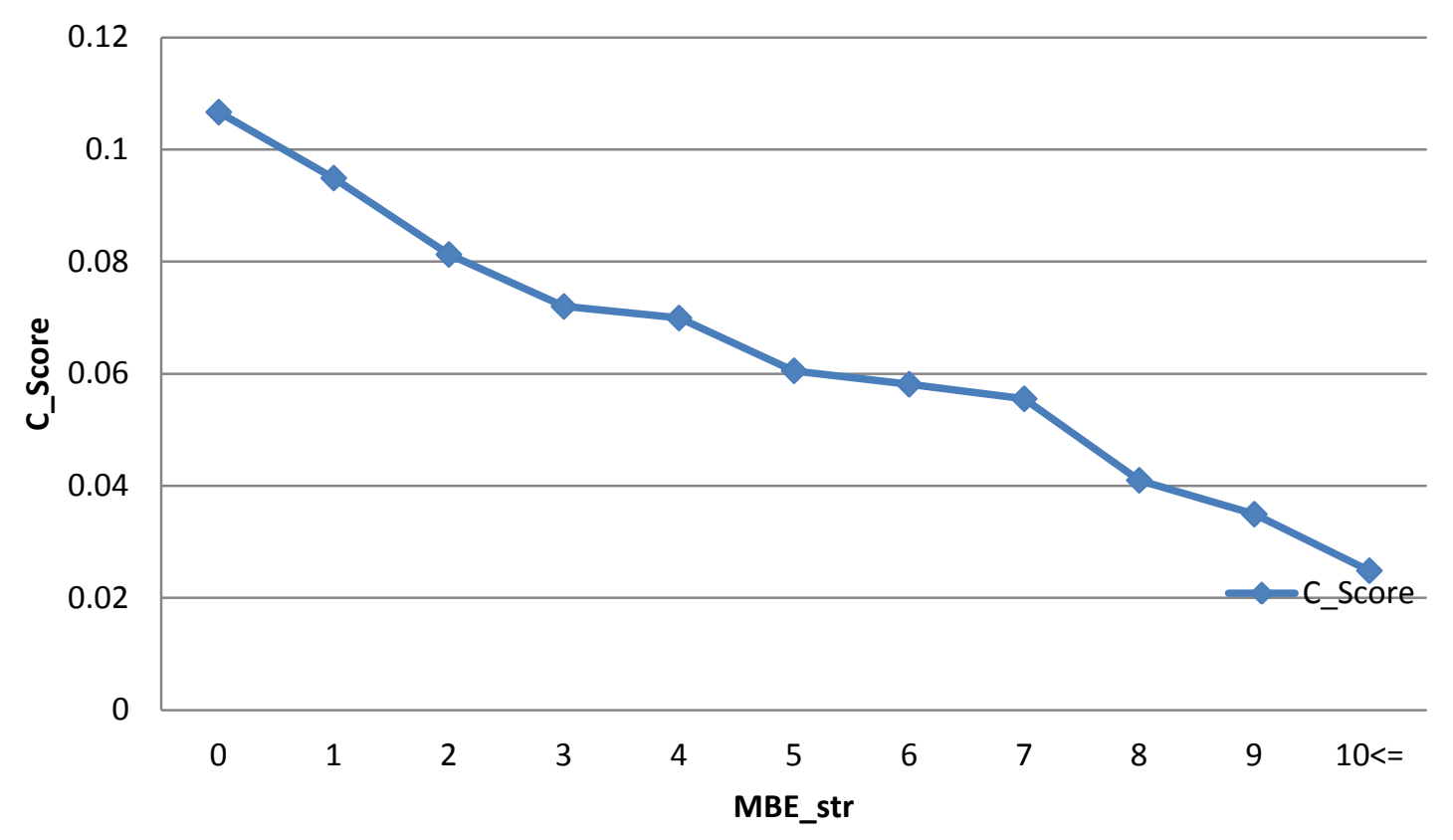

Figure 2 depicts changes of accounting conservatism level as MBE string increases using data in Table 2.

Figure 2: The Level Of Accounting Conservatism Across MBE String

\subsection{Testing Hypothesis 1 And 2}

As we can observe in Figure 2, C_Score clearly decreases as the MBE string increases. Figure 2 itself is strong evidence which supports Hypothesis 1 . In this section of the paper, however, we not only test the association between accounting conservatism and MBE string, but also test underlying mechanism which induces firms to be less conservative as the MBE string increases by using different regression models. Second to the fourth column of Table 4 show results from equation (9) for each management type.

Table 4 shows regression results of equation (9), (10), and (12). Numbers in parenthesis represent the $t$ value for each coefficient. $M B E \_s t r=$ Number of consecutive MBE string years. Exp_Mgt_D = 1 if firms achieve MBE through expectation-management-only and 0 otherwise. Ern_Mgt_D $=1$ if firms achieve MBE through earnings-management-only and 0 otherwise. Un_Mgt_D $=1$ if firms achieve MBE without any management activities and 0 otherwise. Ern_Mgt $=$ degree of earnings management needed to achieve MBE, defined as DAPS times Ern_Mgt_D, where DAPS = 'per share' discretionary accruals which equals to DA times lagged asset scaled by common shares outstanding. Inv_Cyc = Decreasing measure of the length of the investment cycle, defined as depreciation expense deflated by lagged assets. BASprd = Bid-Ask spread scaled by the price of the day. Bid-Ask spread for a firm year is the average of the daily spread for a year. Vol = Standard deviation of return for a year. $R O A=$ Return on assets, defined as net income deflated by total assets. SIC_D and Yr_D are omitted in this table; * indicates $p$-value $<0.1$, ** indicates $p$-value $<0.05$, and $* * *$ indicates $p$-value $<0.01$. 
Table 4: Regression Results

\begin{tabular}{|c|c|c|c|c|c|}
\hline \multicolumn{6}{|c|}{$\begin{array}{l}\text { Dependent Variable: C_Score } \\
\text { When Mgt_D in Equation (9) is }\end{array}$} \\
\hline & $\underline{\text { Exp Mgt-Only }}$ & Ern Mgt-Only & Un Mgt & $\underline{\text { Equation (10) }}$ & Equation (12) \\
\hline Intercept & $\begin{array}{l}0.0810 * * * \\
(22.98)\end{array}$ & $\begin{array}{l}0.0814 * * * \\
(23.06)\end{array}$ & $\begin{array}{l}0.0805 * * * \\
(22.86)\end{array}$ & $\begin{array}{l}0.0815 * * * \\
(22.77)\end{array}$ & $\begin{array}{l}0.0812^{* * *} \\
(23.03)\end{array}$ \\
\hline MBE_str & $\begin{array}{c}-0.0059 * * * \\
(-28.86)\end{array}$ & $\begin{array}{c}-0.0050 * * * \\
(-23.48)\end{array}$ & $\begin{array}{c}-0.0047 * * * \\
(-22.37)\end{array}$ & $\begin{array}{c}-0.0022 * * * \\
(-6.61)\end{array}$ & $\begin{array}{c}-0.0044 * * * \\
(-16.50)\end{array}$ \\
\hline Exp_Mgt_D & $\begin{array}{c}0.0030^{*} \\
(1.73)\end{array}$ & & & $\begin{array}{c}0.0020 \\
(1.14)\end{array}$ & $\begin{array}{c}0.0019 \\
(1.12)\end{array}$ \\
\hline Exp_Mgt_D*MBE_str & $\begin{array}{l}0.0014 * * * \\
(2.67)\end{array}$ & & & $\begin{array}{c}-0.0022 * * * \\
(-3.79)\end{array}$ & $\begin{array}{l}0.0001 \\
(-0.10)\end{array}$ \\
\hline Ern_Mgt_D & & $\begin{array}{r}-0.0015 \\
(-0.88)\end{array}$ & & $\begin{array}{c}-0.0022 \\
(-1.31)\end{array}$ & \\
\hline Ern_Mgt_D*MBE_str & & $\begin{array}{l}-0.0017 * * * \\
(-3.5)\end{array}$ & & $\begin{array}{c}-0.0044 * * * \\
(-8.04)\end{array}$ & \\
\hline Un_Mgt_D & & & $\begin{array}{c}-0.0075^{* * *} \\
(-4.55)\end{array}$ & $\begin{array}{c}-0.0076 * * * \\
(-4.58)\end{array}$ & $\begin{array}{l}-0.0075^{* * *} \\
\quad(-4.54)\end{array}$ \\
\hline Un_Mgt_D*MBE_str & & & $\begin{array}{c}-0.00148 * * * \\
(-3.13)\end{array}$ & $\begin{array}{c}-0.0040 * * * \\
(-7.43)\end{array}$ & $\begin{array}{c}-0.0018 * * * \\
(-3.67)\end{array}$ \\
\hline Ern_Mgt & & & & & $\begin{array}{c}-0.0019 * * \\
(-2.03)\end{array}$ \\
\hline Ern_Mgt*MBE_str & & & & & $\begin{array}{c}-0.0007 * * \\
(-3.67)\end{array}$ \\
\hline Inv_Cyc & $\begin{array}{c}-0.0292 * * \\
(-2.33)\end{array}$ & $\begin{array}{c}-0.0303 * * \\
(-2.42)\end{array}$ & $\begin{array}{c}-0.0097 \\
(-0.78)\end{array}$ & $\begin{array}{c}-0.0142 \\
(-1.13)\end{array}$ & $\begin{array}{c}-0.0162 \\
(-1.29)\end{array}$ \\
\hline BASprd & $\begin{array}{c}1.6738 * * * \\
(82.88)\end{array}$ & $\begin{array}{c}1.6726 * * * \\
(82.77)\end{array}$ & $\begin{array}{c}1.6675^{* * * *} \\
(82.60)\end{array}$ & $\begin{array}{c}1.6605 * * * \\
(82.32)\end{array}$ & $\begin{array}{c}1.6638 * * * \\
(82.41)\end{array}$ \\
\hline Vol & $\begin{array}{c}0.4494 * * * \\
(18.42)\end{array}$ & $\begin{array}{c}0.4500^{* * * *} \\
(18.45)\end{array}$ & $\begin{array}{c}0.4571 * * * \\
(18.75)\end{array}$ & $\begin{array}{c}0.4610 * * * \\
(18.94)\end{array}$ & $\begin{array}{c}0.4520 * * * \\
(18.54)\end{array}$ \\
\hline ROA & $\begin{array}{c}-0.0707 * * * \\
(-25.83)\end{array}$ & $\begin{array}{c}-0.0712 * * * \\
(-26.03)\end{array}$ & $\begin{array}{c}-0.0714 * * * \\
(-26.30)\end{array}$ & $\begin{array}{c}-0.0688 * * * \\
(-25.09)\end{array}$ & $\begin{array}{c}-0.0703 * * * \\
(-25.69)\end{array}$ \\
\hline \# of obs. & 34229 & 34229 & 34229 & 34229 & 34229 \\
\hline Adjusted R $\mathbf{R}^{2}$ & 0.4153 & 0.4154 & 0.4167 & 0.4193 & 0.4175 \\
\hline
\end{tabular}

For each regression model, we include each management type dummy variable as well as its interaction term with the MBE string. In equation (9), the variables of interest are $M B E \_s t r, M g t \_D\left(E x p \_M g t \_D, E r n \_M g t \_D\right.$ or $\left.U n \_M g t \_D\right)$, and $M g t \_D^{*} M B E \_s t r$.

Consistent with the prediction in Hypothesis 1, we find significantly negative coefficients on $M B E \_s t r$ for all management type cases. The coefficient on Ern_Mgt_D is insignificant $(-0.0015$ with $t$-statistic -0.88$)$, but that of $E r n \_M g t D^{*} M B E \_s t r$ is negative and significant at the $1 \%$ level $(-0.0017$ with $t$-statistic -3.5$)$. This implies that firms that engage in earnings management to achieve MBE lowers their level of accounting conservatism and it comes into focus as MBE string increase, which is consistent with both Hypothesis 1 and 2.

In addition, we find that the coefficient of Exp_Mgt_D is positive and only marginally significant $(0.0030$ with $t$-statistic 1.73). And Exp_Mgt_D*MBE_str is also positive and significant at the $1 \%$ level. (0.0014 with $t$ statistic 2.67). Although we do not make any assumption on the impact of expectation management on accounting conservatism, results indicate that firms that engage in expectation management do not lower ones' level of accounting conservatism.

Surprisingly, the coefficients of Un_Mgt_D (-0.0075 with $t$-statistic -4.55$)$ and that of Un_Mgt_D*MBE_str $(-0.00148$ with $t$-statistic -3.13$)$ are negative and significant at the $1 \%$ level. Unmanaged firms, by definition, indicate firms that do not engage in either earnings management or expectation management when trying to achieve MBE. However, it is also possible that there are firms that actually engage in earnings management activity even if they are classified as Unmanaged firms, due to the misspecification of modified Jones model (Dechow et al., 1995). Another possible explanation is that it is an inherent nature of firms that achieve MBE 
by ones' own efforts (i.e., without any management activities) having low level of accounting conservatism as they often incorporate 'good news' in earnings report.

Fifth column in Table 4 shows estimates of equation (10). In this equation, we include all management dummy variables. Since all three cases are mutually exclusive, it is possible to estimate marginal effects of each management on accounting conservatism. Results indicate that the coefficient of $M B E_{-}$str is negative and significant at the $1 \%$ level $(-0.0022$ with $t$-statistic -6.61$)$ even after controlling for all management dummy variables. Interestingly, the coefficient of Exp_Mgt_D becomes insignificant $(0.0020$ with $t$-statistic 1.14$)$ while Exp_Mgt_D*MBE_str is still negative and significant at the $1 \%$ level (-0.0022 with t-statistic -3.79$)$. However, one can argue that the negative and significant coefficient of Exp_Mgt_D*MBE_str is driven by strong influence of $M B E \_s t r$. The coefficient of $E r n \_M g t \_D$ is negative but insignificant (-0.0022 with $t$-statistic -1.31) in equation (10) while that of Ern_Mgt_D*MBE_str is negative and significant at the $1 \%$ level (-0.0044 with $t$-statistic -8.04). Finally, coefficients of $U n_{-} M g t \_D$ and $U n \_M g t D^{*} M B E_{-} s t r$ are negative and significant at the $1 \%$ level $(-0.0076$ with $t$-statistic -4.58 and -0.0040 with $t$-statistic -7.43 respectively). In sum, results in equation (10) reconfirm results in equation (9).

The best way to control management effects is to use variables with value instead of dummy. The degree of earnings management can be estimated by using equation (11). On the other hand, one cannot estimate the degree of expectation management by its nature. Therefore, we estimate equation (12) which uses Ern_Mgt instead of $E r n \_M g t \_D$ to further test hypothesis. Regression results from equation (12) are similar to previous results, but more aligned with Hypothesis 1 and 2 in this study. First, the coefficient of $M B E \_s t r$ is negative and significant at the $1 \%$ level (-0.0044 with $t$-statistic -16.50), which again support Hypothesis 1. Second, coefficients of Exp_Mgt_D and Exp_Mgt_D*MBE_str are insignificant (0.0019 with $t$-statistic 1.12 and 0.0001 with $t$-statistic -0.10 respectively), which implies that the degree of accounting conservatism is not affected by expectation management. Third, coefficients of Ern_Mgt and Ern_Mgt*MBE_str are negative and significant at the 5\% level (-0.0019 with $t$-statistic -2.03 and -0.0007 with $t$-statistic -2.31 ), which is consistent with Hypothesis 1 and 2. This suggests that firms become less conservative as they engage in earnings management to achieve MBE, and the effect is accelerated as the MBE string increases. Finally, coefficients of $U n \_M g t \_D$ and $U n \_M g t \_D^{*} M B E \_s t r$ are negative and significant at the $1 \%$ level (-0.0075 with $t$-statistic -4.54 and -0.0018 with $t$-statistic -3.67 respectively), consistent with previous results. In addition, directions of the coefficients of the control variables are consistent with previous literature and significant at the $1 \%$ level. $^{14}$

Overall, the results from Table 4 are consistent with Hypothesis 1 and 2. Results suggest that the practice of accounting conservatism weakens as firms achieve MBE in consecutive years. In addition, using positive discretionary accruals to achieve MBE hinder firms from the use of conservative accounting.

\subsection{Testing Hypothesis 3}

To test Hypothesis 3, we first convert the S\&P long-term debt credit rating into a numerical value ${ }^{15}$. We assign values in a way that firms with high credit ratings match with high scores. As a result, rating score 21 is assigned for firms with 'AAA' and 1 is assigned for firms with ' $\mathrm{D}$ ' or 'SD'.

Among 36,543 firm-year samples, we first select firms whose MBE string are greater than or equal to 2. Then, we calculate the change of the rating score/C_Score by differencing the rating score/C_Score of the starting year (in which the MBE string starts) from the rating score/C_Score of the ending year (in which the MBE string ends). This procedure reduces the number of observations drastically due to their scarcity in S\&P data. The final number of observations used in testing Hypothesis 3 is 947.

\footnotetext{
${ }^{14}$ Except Inv_Cyc in some cases, all other control variables are significant at the $1 \%$ level.

${ }^{15}$ We assign numerical value on a scale from 1 to 21 in a way that higher values of rating are associated with better debt ratings and a lower cost of debt. This list can be found on the following WRDS website.

(http://wrds-web.wharton.upenn.edu/wrds/ds/documentation/comp/dataGuide/splticrm.cfm)
} 
Table 5: Association Between The Level Of Accounting Conservatism And Credit Rating

\begin{tabular}{|c|c|c|c|c|c|c|}
\hline \multicolumn{7}{|l|}{ Panel A } \\
\hline \multirow{2}{*}{\multicolumn{2}{|c|}{ Number Of Obs. }} & \multirow[b]{2}{*}{ Direction } & \multicolumn{2}{|l|}{$\Delta$ rating Score } & \multicolumn{2}{|l|}{$\Delta c \_$Score } \\
\hline & & & Mean & T-Statistic & Mean & T-Statistic \\
\hline 185 & & $0<$ & $1.5622 * * *$ & 19.1072 & $-0.0114 *$ & -1.7223 \\
\hline 614 & & $0=$ & 0.0000 & N/A & $0.0096 * *$ & 2.2512 \\
\hline 148 & & $0>$ & $-1.6419 * * *$ & -19.0261 & 0.0015 & 0.1662 \\
\hline \multicolumn{7}{|l|}{ Panel B } \\
\hline \multirow{2}{*}{$\begin{array}{c}\text { Number Of } \\
\text { Obs. }\end{array}$} & \multirow{2}{*}{$\begin{array}{c}\text { \#Of Mbe } \\
\text { String }\end{array}$} & \multirow[b]{2}{*}{ Direction } & \multicolumn{2}{|l|}{$\Delta$ rating Score } & \multicolumn{2}{|l|}{$\Delta c \_$Score } \\
\hline & & & Mean & T-Statistic & Mean & T-Statistic \\
\hline 82 & & $0<$ & $1.3049 * * *$ & 19.6204 & -0.0047 & -0.5050 \\
\hline 480 & $3 \geq$ & $0=$ & 0.0000 & N/A & $0.0126 * *$ & 2.5112 \\
\hline 66 & & $0>$ & $-1.4697 * * *$ & -15.9467 & -0.0013 & -0.0976 \\
\hline 103 & & $0<$ & $1.7670 * * *$ & 13.1948 & $-0.0166^{*}$ & -1.8046 \\
\hline 134 & $3<$ & $0=$ & 0.0000 & N/A & -0.0009 & -0.1139 \\
\hline 82 & & $0>$ & $-1.7805 * * *$ & -13.1347 & 0.0037 & 0.3241 \\
\hline
\end{tabular}

Table 5 shows changes in level of accounting conservatism and its relationship with credit rating changes in CMBE firms. Among 36,543 firm-year samples, we select firms whose MBE string is greater than or equal to 2. And then, we calculate the change of the rating score $\left(C \_S c o r e\right)$ by differencing the rating score $\left(C_{-} S c o r e\right)$ of the starting year (in which the MBE string starts) from the rating score (C_Score) of the ending year (in which the MBE string ends); * indicates $p$-value $<0.1$, ** indicates $p$-value $<0.05$, and *** indicates $p$-value $<0.01$.

Panel A, in Table 5, reports the corresponding results. The first row represents firms whose rating score had been elevated, whereas the second and third rows represent firms whose rating score shows no change or had fallen. The results are consistent with Hypothesis 3. The change in C_Score is negative and significant at the 10\% level (0.0114 with t-statistic -1.722 ) within firms whose rating score had been elevated. This suggest that such CMBE firms use less conservative accounting, since the MBE string itself acts as a substitute for conservative accounting as it lowers the firm's cost of debt. In addition, the number of observations whose change in rating score is positive is $25 \%$ greater than that of firms whose change in rating score is negative (185 vs 148). This implies that the market does appreciate firms that achieve MBE in consecutive years and credit where credit is due.

In Panel B, we divide the samples into two subgroups according to each firm's MBE string. The first three rows show results which are obtained from firms whose MBE string is less than or equal to 3. In this subgroup, the difference in C_Score is still negative but the p-value indicates that this change is insignificantly different from zero (0.0047 with $t$-statistic -0.5050). However, in the next subgroup, which is composed of firms whose MBE string is greater than 3, the change in $C \_S c o r e$ is significantly negative (-0.0166 with $t$-statistic -1.8046). Therefore, Panel B results indicate that negative changes in $C_{-}$Score in Panel A are mainly driven by firms whose MBE string is long enough. Overall, results in Table 5 generally support the idea described in Hypothesis 3.

\section{CONCLUSION}

Firms have a great incentive to meet or beat the latest analyst forecast. Since it is one of the important performance thresholds, managers are willing to engage in either expectation management or earnings management to achieve MBE. However, there has been little research concerning CMBE firms.

In this paper, we focused on accounting conservatism of CMBE firms as well as their management behavior. Throughout the study, we find that (1) firms practice less accounting conservatism as MBE string increase, (2) using positive discretionary accruals to achieve MBE lowers firms' level of conservatism, and (3) CMBE firms whose credit rating had been elevated, use less conservative accounting, which implies that the MBE string itself might act as a substitute for conservative accounting.

In our findings, unmanaged firms are accounted for more than 50\% of total MBE firms. And unmanaged firms in this study denote firms that achieve MBE without engaging in any management activities (i.e., these firms achieve MBE with their performance only). Therefore, the result seems to align with the common belief that most 
firms achieve MBE with their own performance and only those who desperate engage in management activities to achieve MBE. However, it is notable that we also find the negative relationship between accounting conservatism and unmanaged firms. When adding unmanaged firms as a dummy variable in the regression model, we can easily find a negative coefficient. This result can be interpreted in three different ways. First, there are possible misclassifications due to the imperfection of a model. Because firms are classified based on various definitions and models, rather than the true management behavior, there might be firms that are classified as unmanaged firms even if they are, in fact, earnings management firms. Second, there might be other types of management that affect firms' level of accounting conservatism, however, not captured in this study. Finally, we can carefully presume unmanaged firms are less conservative by nature since they tend to report 'good news' in a timely manner to meet or beat analyst forecasts.

Another limitation of the study is a lack of variety in measuring the level of accounting conservatism. If one can find the more appropriate measure, the unexplained negative relationship between unmanaged firms and accounting conservatism might be explained. Thus, future study should focus on explaining this negative relationship using various measure of accounting conservatism. By examining different types of management effects, we can better understand the role of accounting conservatism in CMBE firms.

\section{AUTHOR INFORMATION}

Sang Hyun Park is an Assistant Professor of Accounting in Hull College of Business, Georgia Regents University. He received a B.S. degree in Applied Mathematics from Korea Advanced Institute of Science and Technology (KAIST) and a Ph. D. degree in Management Engineering from KAIST College of Business. He is a member of Georgia Society of CPAs (GSCPA) and American Accounting Association (AAA). E-mail: Email: sapark@ gru.edu

Jaywon Lee is an Assistant Professor of College of Business at Korea Advanced Institute of Science and Technology (KAIST). He received a B.S. degree in Business Administration from University of California at Berkeley and a Ph. D. degree in Accounting from Columbia University. E-mail: Email: jaywonlee@kaist.ac.kr

\section{REFERENCES}

1. Ahmed, A., Billings, B., Morton, R., \& Stanford-Harris, M. (2002). The role of accounting conservatism in mitigating bondholder-shareholder conflicts over dividend policy and in reducing debt costs. The Accounting Review, 77(4), 867-890.

2. Bartov, E., Givoly, D., \& Hayn, C. (2002). The rewards to meeting or beating earnings expectations. Journal of Accounting \& Economics, 33(2), 173-204.

3. Basu, S. (1997). The conservatism principle and the asymmetric timeliness of earnings. Journal of Accounting and Economics, 24(1), 3-37.

4. Brown, L. (1997). Analyst forecasting errors: Additional evidence. Financial Analysts Journal, 53(6), 8188 .

5. Burgstahler, D., \& Eames, M. (2006). Management of earnings and analysts' forecasts to achieve zero and small positive earnings surprises. Journal of Business Finance \& Accounting, 33(5-6), 633-652.

6. Campbell, J., \& Hentschel, L. (1992). No news is good news:: An asymmetric model of changing volatility in stock returns. Journal of Financial Economics, 31(3), 281-318.

7. Chen, Q., Hemmer, T., \& Zhang, Y. (2007). On the relation between conservatism in accounting standards and incentives for earnings management. Journal of Accounting Research, 45(3), 541-565.

8. Christie, A. (1982). The stochastic behavior of common stock variances: Value, leverage and interest rate effects. Journal of Financial Economics, 10(4), 407-432.

9. Dechow, P., Sloan, R., \& Sweeney, A. (1995). Detecting earnings management. The Accounting Review, 70(2), 193-225.

10. Degeorge, F., Patel, J., \& Zeckhauser, R. (1999). Earnings management to exceed thresholds. Journal of business, 72(1), 1-33.

11. Easley, D., Hvidkjaer, S., \& O'Hara, M. (2002). Is information risk a determinant of asset returns? Journal of Finance, 57(5), 2185-2221. 
12. Fama, E. F., \& French, K. R. (1997). Industry costs of equity. Journal of Financial Economics, 43(2), 153193.

13. Feltham, G., \& Ohlson, J. (1995). Valuation and clean surplus accounting for operating and financial activities. Contemporary Accounting Research, 12, 689-732.

14. Givoly, D., \& Hayn, C. (2000). The changing time-series properties of earnings, cash flows and accruals: Has financial reporting become more conservative? Journal of Accounting and Economics, 29(3), 287-320.

15. Holthausen, R. W., \& Watts, R. L. (2001). The relevance of the value-relevance literature for financial accounting standard setting. Journal of Accounting and Economics, 31(1-3), 3-75.

16. Hui, K. W., Matsunaga, S., \& Morse, D. (2009). The impact of conservatism on management earnings forecasts. Journal of Accounting and Economics, 47(3), 192-207.

17. Iyengar, R. J., \& Zampelli, E. M. (2010). Does accounting conservatism pay? Accounting and Finance, 50(1), 121-142.

18. Jackson, S. B., \& Liu, X. T. (2010). The Allowance for Uncollectible Accounts, Conservatism, and Earnings Management. Journal of Accounting Research, 48(3), 565-601.

19. Jones, J. J. (1991). Earnings Management during Import Relief Investigations. Journal of Accounting Research, 29(2), 193-228.

20. Kasznik, R., \& McNichols, M. (2002). Does meeting earnings expectations matter? Evidence from analyst forecast revisions and share prices. Journal of Accounting Research, 727-759.

21. Khan, M., \& Watts, R. (2009). Estimation and empirical properties of a firm-year measure of accounting conservatism. Journal of Accounting and Economics, 48(2-3), 132-150.

22. Kothari, S., Leone, A., \& Wasley, C. (2005). Performance matched discretionary accrual measures. Journal of Accounting and Economics, 39(1), 163-197.

23. Kross, W. J., Ro, B. T., \& Suk, I. (2011). Consistency in meeting or beating earnings expectations and management earnings forecasts. Journal of Accounting and Economics, 51(1-2), 37-57.

24. LaFond, R., \& Watts, R. (2008). The Information Role of Conservatism. The Accounting Review, 83(2), 447-478.

25. Lara, J., Osma, B., Penalva, F., \& Pearson, A. (2009). The economic determinants of conditional conservatism. Journal of Business Finance \& Accounting, 36(3-4), 336-372.

26. Matsumoto, D. A. (2002). Management's Incentives to Avoid Negative Earnings Surprises. The Accounting Review, 77(3), 483-514.

27. Pae, J. (2007). Unexpected accruals and conditional accounting conservatism. Journal of Business Finance \& Accounting, 34(5-6), 681-704.

28. Payne, J., \& Robb, S. (2000). Earnings Management: The Effect of Ex Ante Earnings Expectations. Journal of Accounting, Auditing and Finance, 15.

29. Penman, S. H., \& Zhang, X. J. (2002). Accounting conservatism, the quality of earnings, and stock returns. The Accounting Review, 77(2), 237-264.

30. Roychowdhury, S. (2006). Earnings management through real activities manipulation. Journal of Accounting and Economics, 42(3), 335-370.

31. Roychowdhury, S., \& Watts, R. L. (2007). Asymmetric timeliness of earnings, market-to-book and conservatism in financial reporting. Journal of Accounting and Economics, 44(1-2), 2-31.

32. Ryan, S. (2006). Identifying conditional conservatism. European Accounting Review, 15(4), 511-525.

33. Skinner, D., \& Sloan, R. (2002). Earnings surprises, growth expectations, and stock returns or don't let an earnings torpedo sink your portfolio. Review of Accounting Studies, 7(2), 289-312.

34. Watts, R. (2003a). Conservatism in Accounting Part I: Explanations and Implications. Accounting Horizons, 17(3), 207-222.

35. Watts, R. (2003b). Conservatism in Accounting Part II: Evidence and Research Opportunities. Accounting Horizons, 17(4), 287-302.

36. Watts, R. L., \& Zimmerman, J. L. (1990). Positive Accounting Theory: A Ten Year Perspective. The Accounting Review, 65(1), 131-156.

37. Zhang, X. (2000). Conservative accounting and equity valuation. Journal of Accounting and Economics, 29(1), 125-149. 